\title{
Expanding Biohybrid-mediated Asymmetric Catalysis into the Realm of RNA
}

\author{
Nicolas Duchemin, ${ }^{a}$ Erica Benedetti, ${ }^{a}$ Lucas Bethge, ${ }^{b}$ Stefan Vonhoff, ${ }^{b}$ Sven Klussmann, \\ Jean-Jacques Vasseur, ${ }^{\mathrm{c}}$ Janine Cossy, ${ }^{\mathrm{a}}$ Michael Smietana, ${ }^{*, \mathrm{c}}$ and Stellios Arseniyadis, ${ }^{*, a, d}$
}

\begin{abstract}
The recent development of biohybrid catalytic systems has allowed synthetic chemists to reach high levels of selectivity on a wide variety of valuable synthetic transformations. In this context, DNA-based catalysts have emerged as particularly appealing tools. Interestingly, while long RNA sequences (ribozymes) are known to catalyse specific biochemical reactions with remarkable efficiencies, RNA-based catalysts in-volving a catalytically active metal complex interacting in a noncovalent fashion with short sequences have never been evaluated to date. We report here our results, which have led to the first example involving a short RNA-based catalyst.
\end{abstract}

Ten years ago, Roelfes and Feringa published the first article pertaining to the use of double-stranded DNA (dsDNA) as a stereochemical control element in a Diels-Alder reaction. ${ }^{1}$ Distinct from artificial DNAzyme approaches obtained through the systematic evolution of ligands by exponential enrichment processes (SELEX), ${ }^{2}$ this landmark was received with a lot of enthusiasm from scientists working in the field of asymmetric artificial biohybrid-mediated catalysis who, along with the initial authors, extended the concept to several other reactions including asymmetric Michael additions, Friedel-Crafts alkylations as well as fluorinations and cyclopropanations. ${ }^{3}$ In the past few years, many studies have aimed at deciphering structural rationalizations and understanding the main parameters that control the stereochemical outcome of a given DNA-based asymmetric transformation. ${ }^{4}$ Our group recently joined this journey by showing that dsDNA made from $L$ nucleotides instead of the natural occurring $D$ nucleotides could be used to control the selectivity outcome of a reaction and thus allow a trivial and reliable access to both enantiomers. ${ }^{5}$ Following this study, we also reported the first generation of a DNA-based catalyst bound to a cellulose matrix capable of achieving high levels of selectivity on various $\mathrm{Cu}(\mathrm{II})$-catalyzed asymmetric transformations under continuous-flow conditions, ${ }^{6 a}$ as well as new anchoring strategy based on the use of minor groove binders. ${ }^{6 b}$ These results prompted many interrogations regarding the use of ribonucleic acid (RNA) in asymmetric metal-catalyzed reactions. Indeed, compared to dsDNAs, dsRNAs exhibit certain structural differences such as a wide and shallow minor groove groove associated with a deep and narrow major groove with 11 base pairs per turn versus 10 in the case of dsDNA (Figure 1). In addition, dsRNAs bear an additional 2'-OH group which increases their thermal stability by locking the duplex into a compact A-form helix. ${ }^{7}$
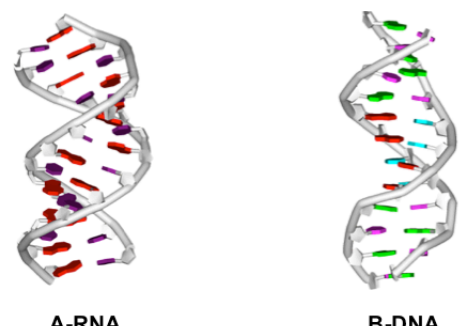

Figure 1. Structural features of right-handed A-RNA and B-DNA.

While it is well known that naturally occurring ribozymes, which are large folded RNA plateforms, catalyze cleavage and juncture of internucleosidic linkages through metal-ion interactions, ${ }^{8}$ artificial ribozymes have also been shown to catalyze various synthetic transformations including Diels-Alders, ${ }^{9}$ Michael additions ${ }^{10}$ aldol condensations, ${ }^{11}$ aminoacylations ${ }^{12}$ and peptide bondforming reactions. ${ }^{13}$ The oxidation of tyramine to the corresponding tyramine dimer using a cyclic dinucleotide riboswitch fused with a G-quadruplex motif has also been recently reported. ${ }^{14}$ Interestingly however, except for a few examples, ${ }^{9 f, 15}$ most of these in vitro-evolved ribozymes require at least one of the reactant to be covalently attached to RNA. Moreover, while the importance of specific cations, such as $\mathrm{Mg}^{2+}$ ions in the case of Diels-Alderase ribozymes, has been demonstrated, ${ }^{16} \mathrm{Cu}^{2+}$ ions were shown to be ineffective. ${ }^{9 c}$ Finally, catalytically active mirror-image ribozymes (Spiegelzymes), which are resistant to nuclease degradation, ${ }^{17}$ have also been described by Jäschke ${ }^{18}$ and Erdmann. ${ }^{19}$

Considering these points and following our previous work pertaining to the use of L-dsDNA in the context of metal-based asymmetric catalysis, we became interested in the potential use of short and defined synthetic L-oligoribonucleotides (L-dsRNA) that lack a catalytically active binding pocket. ${ }^{20}$ Indeed, in contrast with the ribozyme approach, the chiral induction would here result from a non-covalent anchorage of the catalytically active metal complex into the chiral microenvironment provided by the RNA helix. We report here the results of our endeavor, which have led to the first example of an asymmetric Fridel-Crafts alkylation using an RNA-based hybrid catalyst. 
Table 1. Asymmetric Friedel-Crafts catalyzed by L- or D-RNA

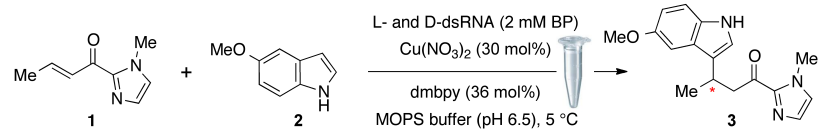

\begin{tabular}{cccc}
\hline Entry & Sequence & Conversion $^{\mathbf{a}}(\%)$ & ee $^{\mathbf{a}}(\%)$ \\
\hline 1 & ORN1 & $>99$ & 0 \\
2 & ORN2 & $>99$ & 0 \\
3 & ORN3 & $>99$ & $(-) 40$ \\
4 & ORN4 & $>99$ & $(+) 40$ \\
5 & ORN5 & $>99$ & 0 \\
6 & ORN6 & 4 & - \\
7 & ORN7 & 94 & $(-) 9$ \\
8 & ORN8 & 98 & $(-) 19$ \\
9 & ORN9 & 96 & $(-) 14$ \\
10 & ORN10 & 96 & $(-) 28$ \\
11 & ORN11 & 96 & $(-) 14$ \\
12 & ORN12 $^{2}$ & 96 & $(-) 19$ \\
13 & ORN3 $^{b}$ & $>99$ & $(-) 8$ \\
14 & ORN3 $^{\mathrm{c}}$ & $>99$ & $(+) 8$ \\
15 & ORN3 $^{\mathrm{d}}$ & 97 & $(+) 2$
\end{tabular}

Conditions: $2 \mathrm{mM}$ base pair solution of RNA in a $20 \mathrm{mM}$ MOPS solution $(400 \mu \mathrm{L} ; \mathrm{pH} 6.5), 0.3 \mathrm{mM}$ of Cu(dmbpy)( $\left.\mathrm{NO}_{3}\right)_{2}$ in a $20 \mathrm{mM}$ MOPS solution $(200 \mathrm{~mL}), 0.5 \mathrm{M}$ solution of enone in $\mathrm{CH}_{3} \mathrm{CN}(1.2 \mu \mathrm{L}), 2.5 \mathrm{M}$
solution of indole in $\mathrm{CH}_{3} \mathrm{CN}(1.2 \mu \mathrm{L}), 1 \mathrm{~d}, 5^{\circ} \mathrm{C}$. a Determined by chiral SFC analysis. ${ }^{\mathrm{b}}$ Reaction performed in the absence of dmbpy. ${ }^{\circ}$ Reaction performed at $21^{\circ} \mathrm{C}$. ${ }^{d}$ Reaction performed at $37^{\circ} \mathrm{C}$. ORN $1=L-5^{\prime}$-(UCAGGGCCC UGA $)_{2}(12 \mathrm{mer})$, ORN2 $=$ D-5'-(UCAGGGCCCUGA $)_{2}(12 \mathrm{mer})$, ORN3 $=$ L-5'-(CAGUCAGUACUGACUG) $)_{2}(16 \mathrm{mer})$ 24mer). ORN6 = L-5'-(GUACGAAUUCGAAGUCAGUCAGGCAGUCAGUCUUUUGACUGACUGCCUGACUGAC

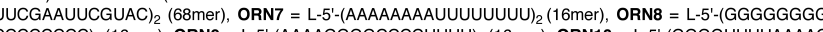
CCCCCCCC $)_{2}(16 \mathrm{mer})$, ORN9 $=$ L-5'-(AAAAGGGGCCCCUUUU $)_{2}(16 \mathrm{mer})$, ORN10 $=$ L-5'-(GGGGUUUUAAAAC (16C) $)_{2}(16 \mathrm{mer})$, ORN11 $=$ L-5' $-(\text { ACUAUCCGCGGAUAGU })_{2}(16 \mathrm{mer})$, ORN12 = L-5' $-(\text { GCCGAUUAUAAUCCGGC })_{2}$ ODR4 $=$ D-5'-(CAGUCAGUACUGACUG) $)_{2}(16 \mathrm{mer})$. ORN5 $=$ L-5'-(UCAGCAUGCAUGCAUGCAUGCUGA)

Our study was initiated using D- and L-RNA sequences which were chosen on the basis of DNA sequences having previously been reported to afford high levels of enantioselectivity. ${ }^{3 f, 5}$ Thus, auto-complementary L- (ORN1) and D- (ORN2) 12mer 5'-(UCAGGGCC CUGA) 2 sequences and L-(ORN3) and D- (ODR4) 16mer 5'-(CAGUCAGUACUGACUG) 2 sequences were prepared and tested. The RNA based asymmetric Cu(II)-catalyzed FriedelCrafts alkylations were performed by reacting $\alpha, \beta$-unsaturated 2-acyl imidazole 1 (0.6 $\mu \mathrm{mol})$ with 5methoxyindole $2(3.0 \mu \mathrm{mol})$ in the presence of $4,4^{\prime}$ dimethyl-2,2'-bipyridine (dmbpy, $36 \mathrm{~mol} \%), \mathrm{Cu}\left(\mathrm{NO}_{3}\right)_{2}$ (30 mol\%) and $2 \mathrm{mM}$ bp of RNA sequences ORN1 to ORN4 in a $20 \mathrm{mM}$ MOPS buffer ( $\mathrm{pH}$ 6.5). The ees of the resulting products was determined by chiral Supercritical Fluid Chromatography (SFC) analysis. The results are summarized in Table 1.

Interestingly and in contrast with the results obtained with dsDNA, the enantioselectivities of the Friedel-Crafts alkylations proved to be highly sequence-dependent. Indeed, while high conversions were obtained with both 12mer and 16mer sequences, ORN1 and ORN2 did not induce any enantioselectivity (Table 1, entries 1 and 2), while ORN3 and ORN4 afforded $40 \%$ ee with an inversion of the selectivity depending on the right- or left-handed nature of the helix (Table 1, entries 3 and 4); an undeniable evidence of chirality transfer. While metal ions cofactors are known to accelerate ribozyme catalysis ${ }^{21}$ a controlled experiment made in the absence of dmbpy led to full conversion albeit only $8 \%$ ee (Table 1 , entry 5 ). This confirmed the importance of the catalytically active metal-complex and suggested that the intrinsic nature of the dsRNA(sequence and length) could induce a favourable outcome through a different mechanism than the one pertaining to ribozymes where the stereoinduction is solely governed by the shape of the catalytic pocket. ${ }^{22}$ Hence, keeping up with sequences having approximately $50 \%$ GC base pairs, we designed and synthesized ORN5, a self-complementary 24mer L-RNA and ORN6 a 68mer L-RNA hairpin (see Supporting Information). Surprisingly, ORN5 only led to a racemic mixture of products albeit with a high conversion, while ORN6 failed to catalyse the reaction. In order to evaluate the influence of the sequence, six additional auto-complementary 16 mer L-oligonucleotides of various base pair compositions (ORN7 = L-5'-(AAAAAAAAUUUUUUUU) 2 , ORN8 = L-5'-(GGGGGGGGCCCCCCCC) 2 , ORN9 = L-5'-(AAAAGGGG CCCCUUUU) 2 , ORN10 = L-5'-(GGGGUUUUAAAACCCC) 2 , ORN11 = L-5'(ACUAUCCGCGGAUAGU) 2 , ORN12 = L-5'-(GCC GAUUAUAAUCCGGC) 2 , Table 1, entries 7-12) were synthesised and evaluated; unfortunately, none of them led to any improvement in selectivity. Finally, increasing the temperature (Table 1 , entries $13-15)$ was detrimental as a complete loss of selectivity was observed when running the reaction at $37^{\circ} \mathrm{C}$.

Table 2. Influence of the co-solvent

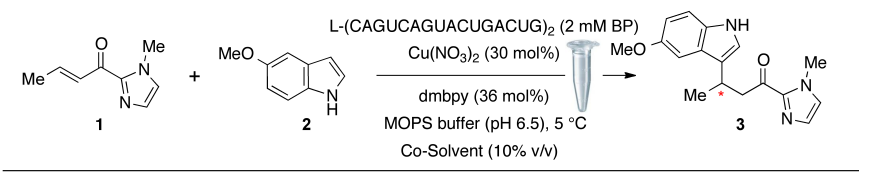

In an attempt to optimize this first set of results, we decided to evaluate the influence of co-solvents and additives. $^{3 e, 23}$ Thus, the Friedel-Crafts alkylation of $\mathbf{1}$ with 5-methoxyindole 2 in the presence of dmbpy, $\mathrm{Cu}\left(\mathrm{NO}_{3}\right)_{2}$ and ORN3 was screened with a variety of organic co-solvents (Table 2). While water-miscible and $\mathrm{H}$-bond supporting solvents such as DMSO, DMF, 1,4-dioxane, acetone and EtOH were tolerated with almost no decrease in conversion, they all induced a clear drop in enantioselectivity (Table 2, entries 1-5). In contrast, the use of $\mathrm{CHCl}_{3}$, which is not miscible with water, did not affect the enantioselective outcome of the reaction, but led to a decrease of the conversion probably due to the higher solubility of the reactants in the organic phase (Table 2, entry 6). Finally, in the presence of $10 \%$ of $\mathrm{MeCN}$ under otherwise identical conditions, a clear increase of the enantioselectivity was observed (ee $=54 \%$, Table 2 , entry 7) confirming earlier results obtained with DNA. ${ }^{23}$ Rising of indole in $\mathrm{CH}_{3} \mathrm{CN}(1.2 \mu \mathrm{L}), 1 \mathrm{~d}, 5^{\circ} \mathrm{C}$. ${ }^{a}$ Determined by chiral SFC analysis.

the amount of acetonitrile was however detrimental to both the conversion and the ee (Table 2, entries 8-9), while the addition of $\mathrm{MgCl}_{2}(10 \mathrm{mM})$ induced a reversal of the selectivity (Table 2, entry 10$)$. Many other attempts were made varying the experimental parameters such as the buffer, the $\mathrm{pH}$ and the ligand (see Supporting Information), however no noticeable improvements were obtained. These results highlight the importance of fine-tuning both the sequence and the reaction conditions in order to achieve high levels on enantioselectivity in the context of RNA-based asymmetric catalysis. 


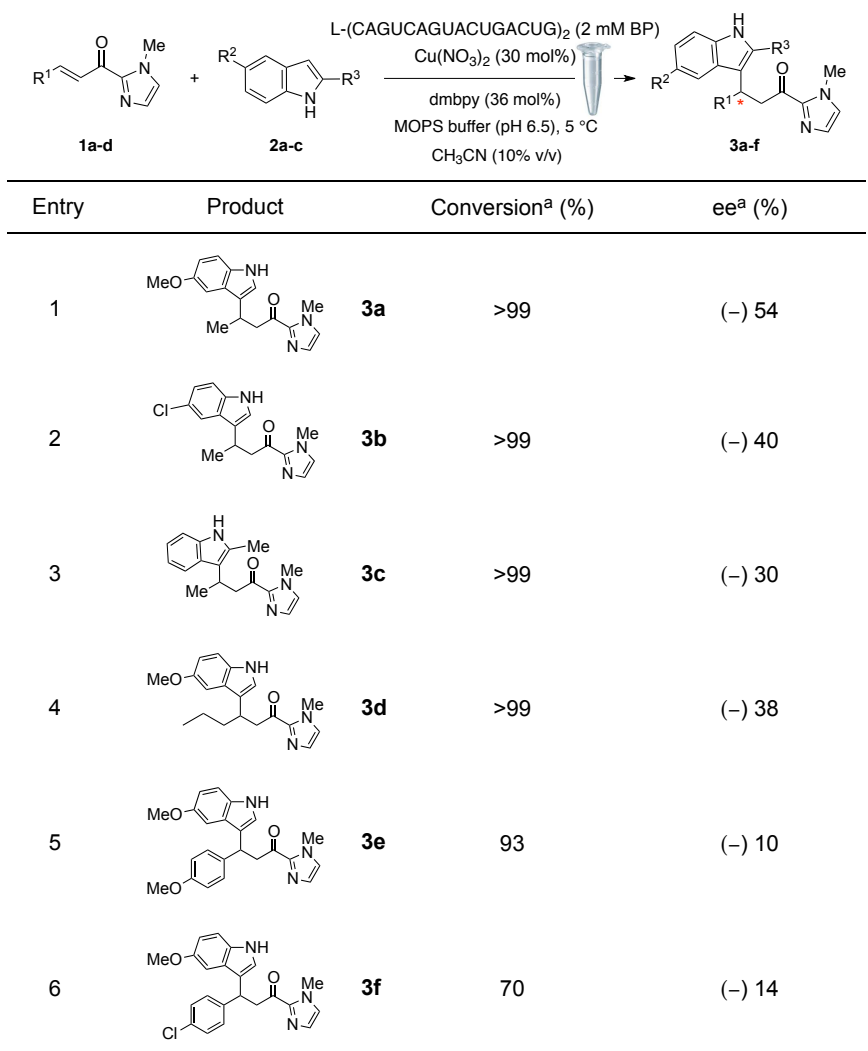

Conditions: $2 \mathrm{mM}$ base pair solution of RNA in a $20 \mathrm{mM}$ MOPS solution ( $400 \mu \mathrm{L} ; \mathrm{pH} 6.5), 0.3 \mathrm{mM}$ of $\mathrm{Cu}$ (dmbpy) $\left(\mathrm{NO}_{3}\right)_{2}$ in a $20 \mathrm{mM}$ MOPS solution $(200 \mathrm{~mL}), 0.5 \mathrm{M}$ solution of enone in $\mathrm{CH}_{3} \mathrm{CN}(1.2 \mu \mathrm{L})$ $2.5 \mathrm{M}$ solution of indole in $\mathrm{CH}_{3} \mathrm{CN}(1.2 \mu \mathrm{L}), 1 \mathrm{~d}, 5^{\circ} \mathrm{C}$. a Determined by chiral SFC analysis.
With this set of conditions in hand, ${ }^{24}$ we next undertook to explore the substrate scope of the reaction. The results are depicted in Table 3 . Hence, in sharp contrast with previously reported data obtained with dsDNA sequences, enones containing an aliphatic substituent were found to be better tolerated than the ones bearing an aromatic group. ${ }^{5}$ As $\pi-\pi$ interactions between the substrates and RNA bases may induce some distortion, this might explain this observation though more studies need to be undertaken in order to fully understand and tame this new type of biohybrid catalytic system.

In summary, this study represents the first example of an asymmetric Friedel-Crafts alkylation using an RNA-based bio-hybrid catalyst. Though modest, the enantioselectivies observed are a manifest proof of concept that small RNA sequences can be used to control the enantioselctive outcome of a given reaction. These results show tremendous promise and underline the many different requirements regarding RNA sequences and folding compared to their ribozymes analogues. A precise understanding of the governing factors is now needed to rationalize and tune the RNA chiral environment into a competitive chiral scaffold.

This research was supported by the Ministère de l'Enseignement Supérieur et de la Recherche and the Agence Nationale de la Recherche (D-CYSIV project; ANR2015-CE29-0021-01).

\section{Notes and references}

${ }^{a}$ Laboratoire de Chimie Organique, Institute of Chemistry, Biology and Innovation (CBI) - ESPCI ParisTech/CNRS (UMR8231)/PSL* Research University, 10 rue Vauquelin, 75231 Paris Cedex 05, France

${ }^{b}$ NOXXON Pharma AG. Max-Dohrn-Strasse 8-10, 10589 Berlin, Germany.

${ }^{c}$ Institut des Biomolécules Max Mousseron, UMR 5247 CNRS, Université de Montpellier, ENSCM Place Eugène Bataillon, 34095 Montpellier, France. E-mail: michael.smietana@umontpellier.fr

${ }^{\mathrm{d} S}$ School of Biological and Chemical Sciences, Queen Mary University of London, Joseph Priestley Building, Mile End Road, London E1 4NS, United Kingdom. E-mail: s.arseniyadis@qmul.ac.uk

+ Electronic Supplementary Information (ESI) available: Details of experimental procedures, ${ }^{1} \mathrm{H}$ NMR and ${ }^{13} \mathrm{C}$ NMR spectra as well as SFC chromatograms. See DOI: 10.1039/c000000x/

1 G. Roelfes, B. L. Feringa, Angew. Chem., Int. Ed. 2005, 44, 3230-3232.

2 I. Willner, B. Shlyahovsky, M. Zayats, B. Willner, Chem. Soc. Rev. 2008, 37, 1153-1165.

3 (a) D. Coquiere, B. L. Feringa, G. Roelfes, Angew. Chem., Int. Ed. 2007, 46, 9308-9311; (b) E. W. Dijk, A. J. Boersma, B. L. Feringa, G. Roelfes, Org. Biomol. Chem. 2010, 8, 3868-3873; (c) E. W. Dijk, B. L. Feringa, G. Roelfes, G. Tetrahedron-Asymmetry 2008, 19, 2374-2377; (d) A. J. Boersma, D. Coquiere, D. Geerdink, F. Rosati, B. L. Feringa, G. Roelfes, Nat. Chem. 2010, 2, 991-995; (e) A. J. Boersma, B. L. Feringa, G. Roelfes, Angew. Chem., Int. Ed. 2009, 48, 3346-3348; (f) A. J. Boersma, J. E. Klijn, B. L. Feringa, G. Roelfes, J. Am. Chem. Soc. 2008, 130, 11783-11790. (g) J. Oelerich, G. Roelfes, Chem. Sci. 2010, 4, 2013-2017; (h) N. Shibata, H. Yasui, S. Nakamura, T. Toru, Synlett 2007, 1153-1157; (i) A. J. Boersma, R. P. Megens, B. L. Feringa, G. Roelfes, Chem. Soc. Rev. 2010, 39, 2083-2092; (j) A. Garcia-Fernandez, G. Roelfes, Metal ions in life sciences 2012, 10, 249-268; (k) S. Park, K. Ikehata, R. Watabe, Y. Hidaka, A. Rajendran, H. Sugiyama, Chem. Commun. 2012, 48, 10398-10400; (I) J. Bos, G. Roelfes, Curr. Opin. Chem. Biol. 2014, 19, 135-143; (m) Y. Li, C. Wang, G. Jia, S. Lu, C. Li, Tetrahedron, 2013, 69, 6585-6589. (n) M. Smietana, J.-J. Vasseur, J. Cossy, S. Arseniyadis (2012) DNA as a Tool for Molecular Discovery, in Modern Tools for the Synthesis of Complex Bioactive Molecules (Eds J. Cossy and S. Arseniyadis), John Wiley \& Sons, Inc., Hoboken, NJ, USA. ch16.

4 (a) M. Wilking, U. Hennecke, Org. Biomol. Chem. 2013, 11, 6940-6945; (b) S. Roe, D. J. Ritson, T. Garner, M. Searle, J. E. Moses, Chem. Commun. 2010, 46, 4309-4311; (c) C. Wang, G. Jia, J. Zhou, Y. Li, Y. Liu, S. Lu, C. Li, C. Angew. Chem., Int. Ed. 2012, 51, 9352-9355; (d) C. H. Wang, Y. H. Li, G. Q. Jia, Y. Liu, S. M. Lu, C. Li, Chem. Commun. 2012, 48, 6232-6234; (e) H. Zhao, K. Shen, RSC Advances 2014, 4, 54051-54059; (f) R. P. Megens, G. Roelfes, Chem. Commun. 2012, 48, 6366-6368; (g) F. Rosati, J. Oelerich, G. Roelfes, Chem. Commun. 
2010, 46, 7804-7806; (h) F. Rosati, A. J. Boersma, J. E. Klijn, A. Meetsma, B. L. Feringa, G. Roelfes, Chem. Eur. J. 2009, 15, 9596-9605; (i) S. Park, L. Zheng, S. Kumakiri, S. Sakashita, H. Otomo, K. Ikehata, H. Sugiyama, ACS Catalysis 2014, 4, 4070-4073; (j) A. J. Boersma, B. de Bruin, B. L. Feringa, G. Roelfes, Chem. Commun. 2012, 48, 2394-2396; (k) Y. Li, G. Jia, C. Wang, M. Cheng, C. Li, ChemBioChem 2015, 16, 618-624; (I) S. Park, I. Okamura, S. Sakashita, J. H. Yum, C. Acharya, L. Gao, H. Sugiyama, ACS Catalysis 2015, 5, 4708-4712; (m) A. RiozMartinez, G. Roelfes, Curr. Opin. Chem. Biol. 2015, 25, 80-87; (n) Y. Li, M. Cheng, J. Hao, C. Wang, G. Jia, C. Li, Chem. Sci. 2015, 6, 5578-5585; (o) A. Draksharapu, A. J. Boersma, W. R. Browne, G. Roelfes, Dalton Trans. 2015, 44, 3656-3663; (p) A. Draksharapu, A. J. Boersma, M. Leising, A. Meetsma, W. R. Browne, G. Roelfes, Dalton Trans. 2015, 44, 3647-3655.

5 J. Wang, E. Benedetti, L. Bethge, S. Vonhoff, S. Klussmann, J.-J. Vasseur, J. Cossy, M. Smietana, S. Arseniyadis, Angew. Chem., Int. Ed. 2013, 52, 11546-11549.

6 (a) E. Benedetti, N. Duchemin, L. Bethge, S. Vonhoff, S. Klussmann, J.-J. Vasseur, J. Cossy, M. Smietana, S. Arseniyadis, Chem. Commun. 2015, 51, 6076-6079; (b) K. Amirbekyan, N. Duchemin, E. Benedetti, R. Joseph, A. Colon, S. A. Markarian, L. Bethge, S. Vonhoff, S. Klussmann, J. Cossy, J.-J. Vasseur, S. Arseniyadis, M. Smietana ACS Catal. 2016, 6, 3096-3105.

7 D. A. Adamiak, J. Milecki, R. W. Adamiak, W. Rypniewski, New J. Chem. 2010, 34, 903-909.

8 W. L. Ward, K. Plakos, V. J. DeRose, Chem. Rev. 2014, 114, 4318-4342.

9 (a) N. Preiswerka, T. Beck, J. D. Schulz, P. Milovník, C. Mayer, J. B. Siegel, D. Baker, D. Hilvert, PNAS 2014 111, 8015-8018; (b) R. R. Breaker, G. F. Joyce, Chem. Biol. 2014, 21, 1059-1065; (c) M. Chandra, S. K. Silverman, J. Am. Chem. Soc. 2008, 130, 2936-2937; (d) T. M. Tarasow, S. L. Tarasow, B. E. Eaton, Nature 1997, 389, 54-57; (e) B. Seelig, A. Jäschke, Chem. Biol. 1999, 6, 167-176; (f) B. Seelig, S. Keiper, F. Stuhlmann, A. Jäschke, Angew. Chem. Int. Ed. 2000, 39, 4576-4579.

10 G. Sengle, A. Eisenführ, P. S. Arora, J. S. Nowick, M. Famulok, Chem. Biol. 2001, 8, 459-473.

11 S. Fusz, A. Eisenführ, S. G. Srivatsan, A. Heckel, M. Famulok, Chem. Biol. 2005, 12, 941-950.

12 M. Illangasekare G. Sanchez, T. Nickles, M. Yarus, Science 1995, 267, 643-647; (b) N. V. Chumachenko, Y. Novikov, M. Yarus, J. Am. Chem. Soc. 2009, 131, 5257-5263.

13 P. A. Lohse, J. W. Szostak, Nature 1996, 381, 442-444; (b) B. Zhang, T. R. Cech, Nature 1997, 390, 96-100; (c) B. Zhang, T. R. Cech, Chem. Biol. 1997, 4, 675-683.

14 G. Tsuji, H. O. Sintim, Mol. BioSyst. 2016, 12, 773-777.

15 F. Huang, Z. Yang, M. Yarus, Chem. Biol. 1998, 5, 669-678.

16 T. Bereźniak, M. Zahran, P. Imhof, A. Jäschke, J. C. Smith, J. Am. Chem. Soc. 2010, 132, 12587-12596.

17 (a) S. Klussmann, A. Nolte, R. Bald, V. A. Erdmann, J. P. Fürste, Nat. Biotechnol. 1996, 14, 1112-1115; (b) A. Vater, S. Klussmann, Drug Discov. Today 2015, 20, 147-155.

18 B. Seelig, S. Keiper, F. Stuhlmann, A. Jäschke, Angew. Chem., Int. Ed. 2000, 39, 4576-4579.

19 (a) E. Wyszko, M. Szymański, H. Zeichhardt, F. Müller, J. Barciszewski, V. A. Erdmann, PloS ONE 2013, 8, e54741. (b) K. Hoehlig, L. Bethge, S. Klussmann, PloS ONE 2015, 10, e0115328.

20 M. Raynal, P. Ballester, A. Vidal-Ferranab, P. W. N. M. van Leeuwena, Chem. Soc. Rev. 2014, 43,1734-1787.

21 (a) E. Biondi, R. R. Poudyal, J. C. Forgy, A. W. Sawyer, A. W. R. Maxwell, D. H. Burke, Nucl. Acids Res. 2013, 41, 3327-3338; (b) J. Schnabl, R. K. O. Sigel, Curr. Opin. Chem. Biol. 2010, 14, 269-275.

22 A. Serganov, S. Keiper, L. Malinina, V. Tereshko, E. Skripkin, C. Höbartner, A. Polonskaia, A. T. Phan, R. Wombacher, R. Micura, Z. Dauter, A. Jäschke, D. J. Patel, Nat. Struct. Mol. Biol. 2005, 12, 218-224.

23 R. P. Megens, G. Roelfes, Org. Biomol. Chem. 2010, 8, 1387-1393.

24 General procedure for the RNA-catalysed Friedel-Crafts alkylation. To a $3 \mathrm{mM}$ base pair solution of the desired RNA sequence in a $20 \mathrm{mM}$ MOPS buffer $(400 \mu \mathrm{L})$ was added a $0.9 \mathrm{mM}$ solution of $\left[\mathrm{Cu}(\mathrm{dmbpy})\left(\mathrm{NO}_{3}\right)_{2}\right]$ in a $20 \mathrm{mM}$ MOPS buffer $(200 \mu \mathrm{L})$. The resulting solution ( $2 \mathrm{mM}$ base pair, $600 \mu \mathrm{L}$ ) was cooled to $5{ }^{\circ} \mathrm{C}$. To the cold mixture was added a $0.5 \mathrm{M}$ solution of enone in MeCN (1.2 $\left.\mu \mathrm{L}\right)$, followed by a $2.5 \mathrm{M}$ solution of substituted indole in $\mathrm{MeCN}(1.2 \mu \mathrm{L})$. The reaction was mixed by inversion at $5{ }^{\circ} \mathrm{C}$ in a cold room. After $1 \mathrm{~d}$, the mixture was warmed to $\mathrm{rt}$ and extracted with $\mathrm{Et}_{2} \mathrm{O}(3 \times 2 \mathrm{~mL})$. The combined organic layers were washed with brine $(2 \mathrm{~mL}), \mathrm{dried}$ over $\mathrm{Na}_{2} \mathrm{SO}_{4}$, filtered through a plug of silica gel and concentrated under reduced pressure, to give the crude product which was subjected to SFC analysis without further purification. 